\title{
Pengembangan Aplikasi Web Untuk Penentuan Nutrisi Anak Dengan Metode Fuzzy C-Means Berdasarkan Produk Kemasan
}

\author{
Nur Rachmaliany ${ }^{* 1}$, Sri Winiarti ${ }^{2}$, Herman Yuliansyah ${ }^{3}$ \\ 1,2,3 Universitas Ahmad Dahlan \\ emmarachmaliany@gmail.com ${ }^{* 1}$, sri.winiarti@tif.uad.ac.id ${ }^{2}$, herman.yuliansyah@tif.uad.ac.id ${ }^{3}$
}

\begin{abstract}
Abstrak
Orang tua perlu memperhatikan kualitas dan standar kesehatan produk yang dikonsumsi oleh anaknya. Orang tua juga perlu secara cermat memperhatikan komposisi penggunaan bahan baku pada produk kemasan yang beredar di pasaran. Penelitian ini bertujuan untuk mengembangkan aplikasi web untuk penentuan nutrisi anak dengan metode Fuzzy C-Means. Hasil penentuan diperoleh dari mempertimbangkan beberapa indikator seperti umur, berat badan (BB), tinggi badan (TB). Tahap pengembangan aplikasi adalah perancangan sistem dengan pembuatan basis pengetahuan, membuat model keputusan dengan algoritma Fuzzy C-Means, dan basis aturan, perancangan proses terdiri dari pembuatan proses bisnis, diagram konteks, diagram aliran data (DAD), struktur menu, desain antarmuka sistem, implementasi, dan pengujian sistem dengan menggunakan metode User Acceptance Test (UAT), Usability Testing (UT), pengujian knowledge, dan validasi Fuzzy C-Means. Hasil dari penelitian ini adalah aplikasi web untuk penentuan nutrisi anak usia 7 bulan sampai 6 tahun yang membantu orang tua untuk mengetahui status gizi anak, dan juga dapat merekomendasikan produk kemasan yang dapat dikonsumsi anak. Hasil dari pengujian User Acceptance Test sebesar 89\% dapat menerima, pengujian Usability Testing sebesar $74,87 \%$ sesuai, pengujian knowledge sebesar $79 \%$ sesuai, dan validasi penerapan Fuzzy C-Means sebesar $83 \%$.
\end{abstract}

Kata kunci: Metode Fuzzy C-Means, Nutrisi, Produk Kemasan, Aplikasi Web

\begin{abstract}
Parents need to pay attention to product quality and health standards, which are consumed by their children. Parents also need to carefully consider the composition of the packaged food products in the market. This research aims to develop a web application to determine the nutrition of children with fuzzy c-means. The results of the determination of nutrients, obtained from considering some indicators such as age, body weight, height. The application development stage is a system designs by making knowledge base, making a decision model with algorithms fuzzy c-means, the rule base. The design process consists of: making business processes, context diagrams, Diagram Flow Data (DFD), the menu structure, interface design system, implementation, and testing of the system by using the User Acceptance Test (UAT), Usability testing (UT), Knowledge testing and Validation Fuzzy C-Means. Results of this research is a web application to determine the nutrition of children ages 7 months to 6 years, which helps parents to know about the nutritional status of their children. In addition, web applications can also recommend the product packaging that can be consumed by children. UAT results declared by $89 \%$ can receive web applications, UT results declared by $74.87 \%$ accepted. Results of testing the knowledge declared by $79 \%$ compliance, and validation of the application of fuzzy c-means is equal to $83 \%$.
\end{abstract}

Keywords: Fuzzy C-Means Method, Nutrition, Package food products, Web Applications

\section{Pendahuluan}

Masalah gizi pada hakikatnya adalah masalah kesehatan masyarakat, namun penanggulangannya tidak dapat dilakukan dengan pendekatan medis dan pelayanan kesehatan saja. Masalah gizi di Indonesia dan di Negara berkembang masih didominasi oleh masalah Kurang Energi Protein (KEP), masalah anemia besi, masalah Gangguan Akibat Kekurangan Yodium (GAKY), masalah Kurang Vitamin A (KVA) dan masalah obesitas terutama di kota-kota besar yang perlu ditanggulangi [1]. Permasalahan KEP atau gizi kurang yang sering ditemukan 
terutama pada anak biasa disebut gizi buruk dan merupakan masalah yang sulit ditanggulangi oleh pemerintah.

Di tengah maraknya berbagai macam produk kemasan untuk anak yang beredar di pasaran, maka orang tua perlu memperhatikan kualitas produk serta standar kesehatan produk yang dipakai dan dikonsumsi oleh anak termasuk salah satunya cermat terhadap komposisi penggunaan bahan baku. Kebutuhan anak akan nutrisi cenderung meningkat seiring dengan pertambahan usianya. Munculnya berbagai jenis produk tersebut di pasaran saat ini seiring dengan kemajuan teknologi yang telah berhasil menciptakan produk yang disesuaikan dengan pertambahan usia anak.

Saat ini telah banyak penelitian yang membangun sistem tentang penentuan status gizi pada balita dengan berbagai macam metode, antara lain menggunakan metode Analitycal Hierarchy Proses (AHP) [2], metode Certainty Factor [1], metode Forward Chaining [3], dan metode Naive Bayes Classifier [4] [5], Jaringan Syaraf Tiruan dengan metode Backpropagation [6] dan jaringan syaraf tiruan menggunakan algoritma Perceptron [7], Metode Fuzzy Inferensi Sugeno [8] dan metode K-Nearest Neighbor [9]. Sistem tersebut menganalisis status gizi balita dengan mempertimbangkan beberapa indikator seperti umur, jenis kelamin (JK), tinggi badan (TB), dan berat badan (BB). Akan tetapi sistem tersebut hanya menganalisis status gizi pada balita, apakah balita tersebut menderita gizi buruk, gizi normal atau gizi lebih dan tidak memberikan rekomendasi terhadap produk makanan dalam kemasan yang akan dikonsumsi sehingga selain menentukan status gizi, penelitian ini juga akan memberikan rekomendasi terhadap produk kemasan yang dapat dikonsumsi sesuai dengan nilai status gizi balita tersebut.

Selain penelitian terkait penentuan status gizi balita tersebut, terdapat juga beberapa penelitian terkait yang juga menghasilkan sebuah aplikasi diantaranya adalah rancang bangun aplikasi penilaian status gizi dan penentuan menu makanan yang menghasilkan Aplikasi yang dapat melakukan penilaian status gizi terhadap usia anak-anak, usia remaja dan orang dewasa dengan menggunakan Indeks Massa Tubuh serta dapat menentukan menu makanan yang sesuai dengan kebutuhan kalori harian [10]. Terdapat juga penelitian lain terkait aplikasi, yaitu aplikasi penentuan komposisi bahan pangan harian yang optimal untuk mencukupi kebutuhan nutrisi dalam 1 hari dengan algoritma genetika [11].

Sebuah sistem perlu dikembangkan untuk mengetahui status gizi pada anak. Selain itu sistem juga dapat memberikan rekomendasi terhadap produk kemasan dapat dikonsumsi atau tidak. Sehingga pada penelitian ini dikembangkan suatu sistem penentuan nutrisi anak dengan metode Fuzzy C-Means (FCM). Metode FCM dalam sistem ini membantu cluster atau mengelompokkan status gizi anak dengan mempertimbangkan beberapa indikator seperti umur, tinggi badan (TB), dan berat badan (BB). Sistem ini menganalisis produk kemasan yang mengandung nutrisi yang dibutuhkan anak dengan mempertimbangkan status gizi anak tersebut dengan cara menambahkan kode batang pada kemasan.

Penelitian ini mengacu pada penelitian terdahulu yang telah dilakukan [12]. Pada penelitian tersebut membahas mengenai mengklasifikasikan bahan pangan berdasarkan kandungan nutrisinya. Proses clustering dibagi menjadi empat golongan, yaitu golongan hijau, golongan kuning, golongan jingga, dan golongan merah.

Penelitian ini juga mengacu pada penelitian terdahulu yang telah dilakukan [4]. Penelitian ini melakukan pencarian pola status gizi yang sering dialami oleh pasien anak yang mana bisa dideteksi dari informasi yang terkandung dalam kumpulan rekam medis. Atribut yang digunakan adalah jenis kelamin, umur, tinggi badan, berat badan, dan tiga buah komorbid (diare, edema, dan pneumonia).

Penelitian ini juga mengacu pada penelitian terdahulu yang telah dilakukan [13]. Penelitian ini menghasilkan sebuah aplikasi Android yang dapat dijadikan sebagai mesin pengingat bagi orang tua ketika akan membeli produk makanan dapat mengetahui informasi terkait makanan tersebut yang tidak menjadi pantangan bagi penyakitnya berdasarkan informasi kandungan makanan yang tertera pada kemasan produk makanan.

\section{Metode Penelitian \\ 2.1 Subjek Penelitian}

Subjek dalam penelitian ini adalah bagaimana menganalisis suatu sistem dalam menentukan status gizi yang dibutuhkan anak dengan mempertimbangkan beberapa indikator seperti umur, berat badan (BB), tinggi badan (TB), nutrisi yang dibutuhkan dan produk kemasan yang diimplementasikan dalam web. Hasil yang akan diberikan berupa status gizi anak dan rekomendasi produk kemasan yang dapat dikonsumsi. 


\subsection{Metode Pengumpulan Data}

Pengumpulan data dilakukan dengan studi literatur dan wawancara. Studi literatur dilakukan dengan cara mencari, mempelajari, dan memahami buku-buku referensi, laporan skripsi, jurnal penelitian, artikel penelitian maupun browsing internet yang berhubungan dengan nutrisi anak dan status gizi pada anak, dan juga penerapan metode Fuzzy C-Means (FCM). Metode pengumpulan data yang dipakai pada penelitian ini berupa kajian pustaka, wawancara dan percobaan. Sedangkan wawancara dilakukan dengan mengadakan tanya jawab kepada para ibu-ibu yang memiliki anak usia 7 bulan sampai 6 tahun di daerah Madukismo, Yogyakarta, mengenai beberapa kendala yang dihadapi dalam memilih makanan produk kemasan yang baik untuk di konsumsi.

\subsection{Tahap Pengembangan Sistem}

Tahapan pada pengembangan sistem meliputi:

1. Analisis kebutuhan, menganalisis data apa saja yang dibutuhkan sistem agar sesuai dengan tujuan dibangunnya sistem. Mulai dari data apa saja yang harus ditambahkan, data yang harus diproses, dan data apa saja yang harus disimpan di database sehingga menghasilkan output yang diinginkan.

2. Perancangan Sistem, perancangan sistem ini yang dirancang adalah komponen perangkat lunak (software). Tahapan-tahapan perancangan sistem, yaitu basis pengetahuan, membuat model keputusan dengan algoritma FCM dalam bentuk flowchart, dan membuat basis aturan.

3. Pemodelan proses, merupakan gambaran proses pengolahan data yang terjadi pada sistem. Pemodelan proses digambarkan menggunakan diagram konteks, mulai dari data apa saja yang ditambahkan kemudian data tersebut diproses dan menghasilkan output berupa keputusan.

\subsection{Implementasi}

Setelah menentukan tahap pengembangan sistem, selanjutnya sistem ini akan diimplementasikan dengan menggunakan bahasa pemrograman PHP, kemudian menampilkan ke dalam sebuah web server dengan melakukan komputerisasi terhadap seluruh data dan informasi yang didapat dari penelitian sehingga dihasilkan suatu sistem penentuan nutrisi secara cepat, tepat, dan akurat.

\subsection{Pengujian Sistem (Testing)}

Untuk mengoptimalkan bagaimana sistem ini bekerja dengan baik, maka sistem akan masuk dalam tahap pengujian. Pengujian sistem yang digunakan, yaitu User Acceptance Test (UAT), Usability Testing (UT), pengujian knowledge, dan validasi Fuzzy C-Means.

\section{Hasil Penelitian dan Pembahasan}

\subsection{Analisis Kebutuhan}

Analisis kebutuhan sistem yang dibutuhkan meliputi:

1. Data masukan (input), data masukan yang diperlukan berupa data acuan nilai nutrisi yang nantinya akan digunakan untuk membangun suatu keputusan, data anak, data produk, data aturan, dan data rekomendasi.

2. Data keluaran (output), output yang dihasilkan yaitu dapat menampilkan status gizi anak, dan juga dapat menampilkan rekomendasi produk yang dapat dikonsumsi.

\subsection{Perancangan Sistem}

1. Basis Aturan, dalam sistem ini basis aturan berisi aturan-aturan yang nantinya digunakan sebagai acuan dalam mengambil suatu keputusan. Tabel basis aturan disusun berdasarkan basis pengetahuan dan juga hasil wawancara dengan pakar gizi dari Fakultas Kesehatan Masyarakat di Universitas Ahmad Dahlan, yaitu Atikah Rahayu, S.KM., M.PH.

2. Proses Bisnis

Gambar 1 menjelaskan sekumpulan aktivitas terstruktur yang berisi proses-proses yang terjadi di dalam sistem dan siapa saja yang terlibat di dalam sistem. 


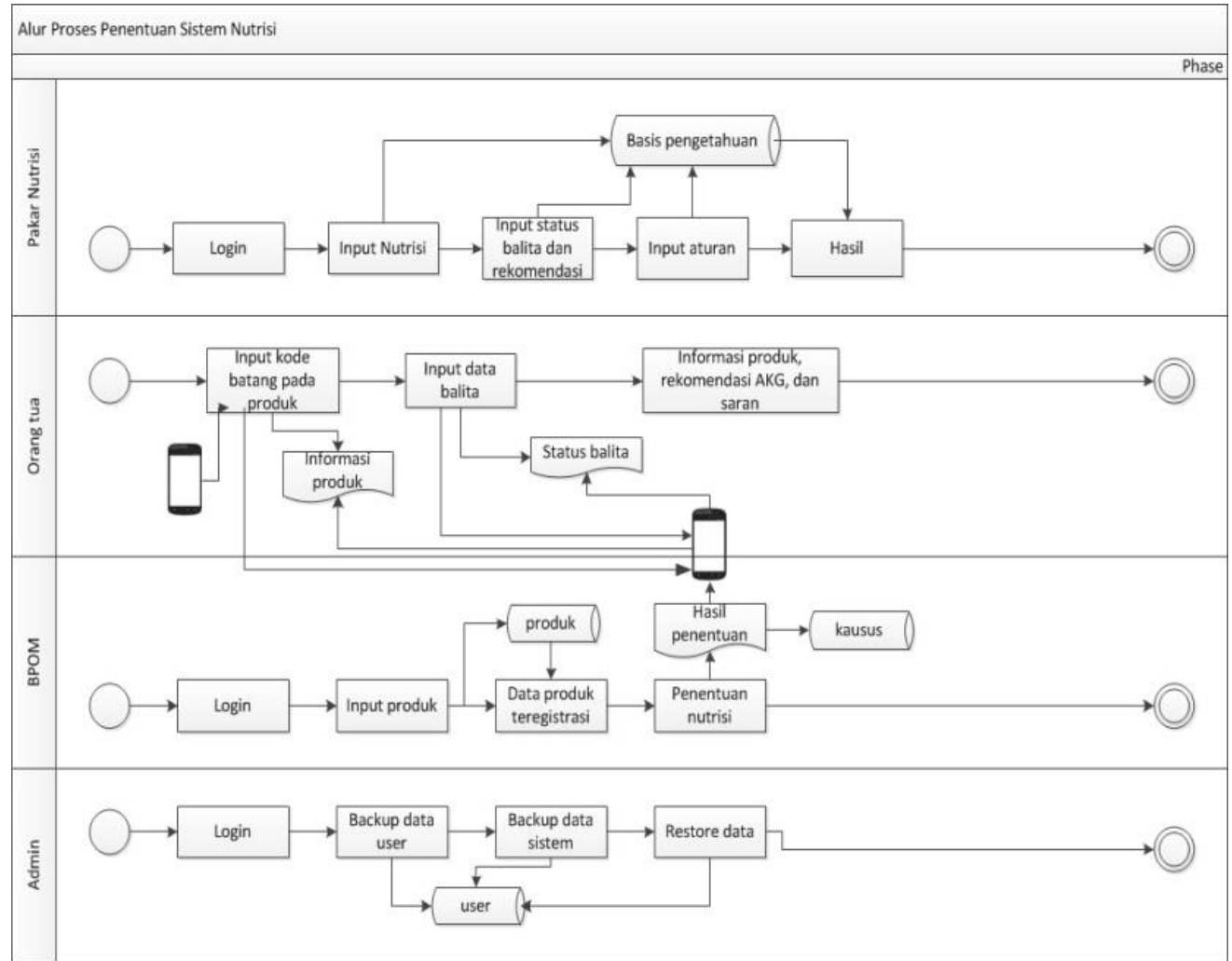

Gambar 1. Proses Bisnis

\subsection{Pemodelan Proses}

\subsubsection{Diagram Konteks}

Diagram Konteks menjelaskan alur yang terjadi dalam sistem ini secara umum seperti pada Gambar 2. Mulai dari data apa saja yang ditambahkan kemudian data tersebut diproses dan menghasilkan output berupa keputusan.

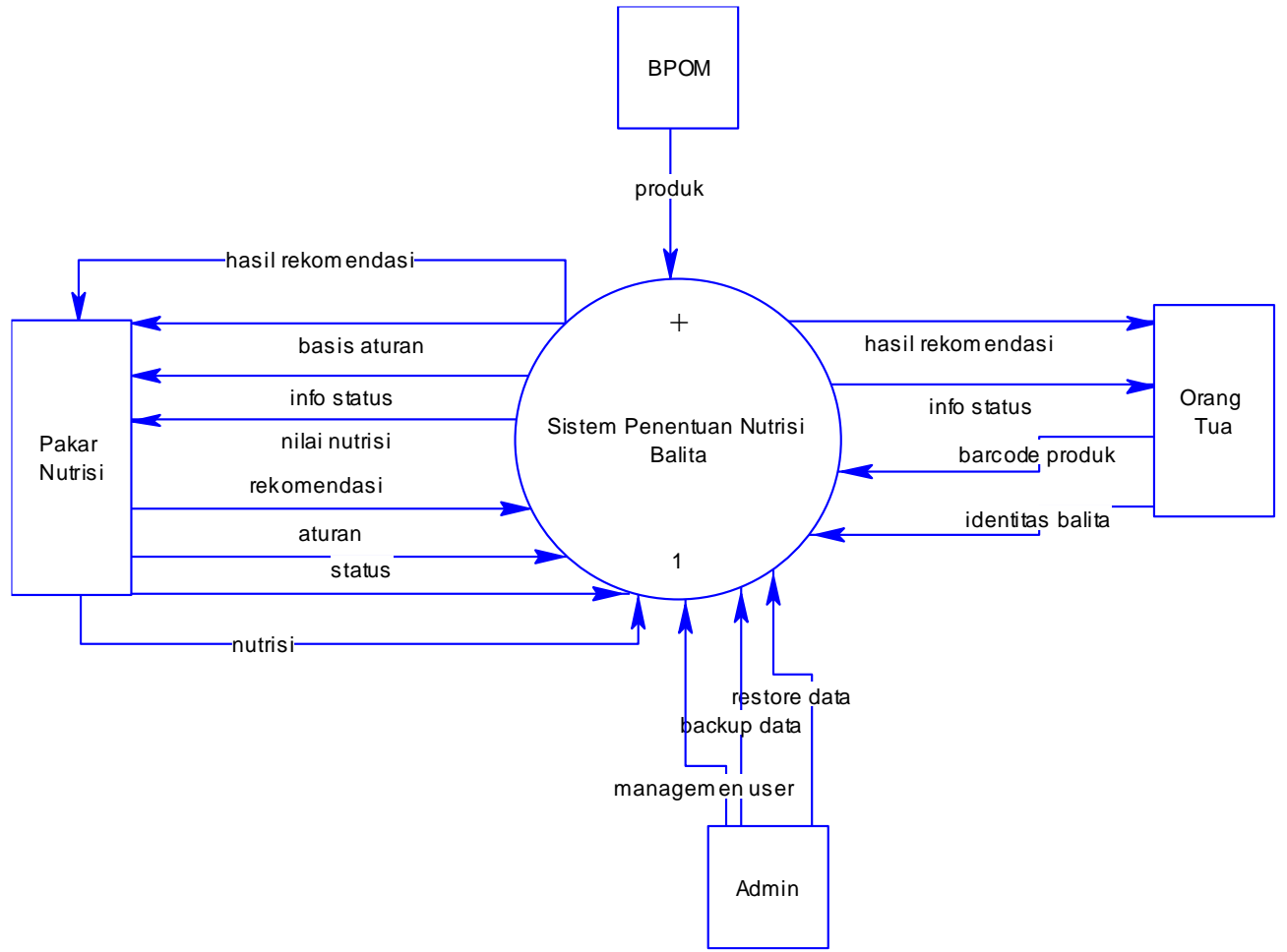

Gambar 2. Diagram Konteks

KINETIK Vol. 2, No. 2, Mei 2017: 107-116 


\subsubsection{Diagram Alir Data}

Gambar 3 menjelaskan secara mendetail arus yang terdapat pada sistem penentuan nutrisi anak. Dari diagram tersebut pakar bertugas memberikan input basis pengetahuan. Orang tua melakukan registrasi terlebih dahulu dengan mengisikan identitas anak, dan memasukkan kode batang (barcode). Setelah itu akan di proses menggunakan algoritma FCM.

Gambar 4 menjelaskan proses yang dilakukan seorang pakar untuk membangun sebuah basis pengetahuan dan memberikan rekomendasi. Kemudian Gambar 5 menjelaskan alur pada sistem, mulai dari menentukan status gizi setelah itu sistem memberikan hasil rekomendasi kepada pengguna (orang tua).

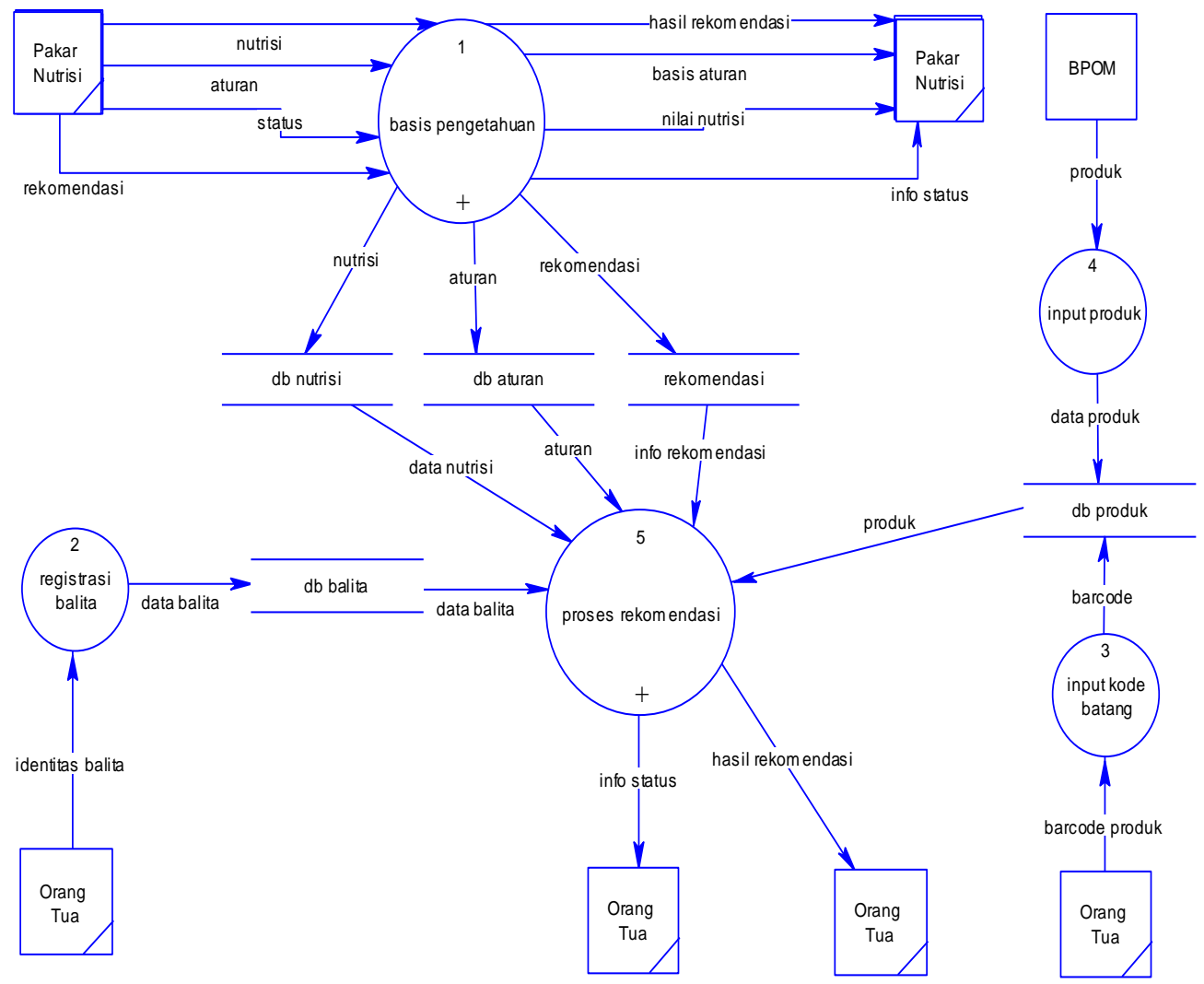

Gambar 3. Diagram Alir Data Level 0

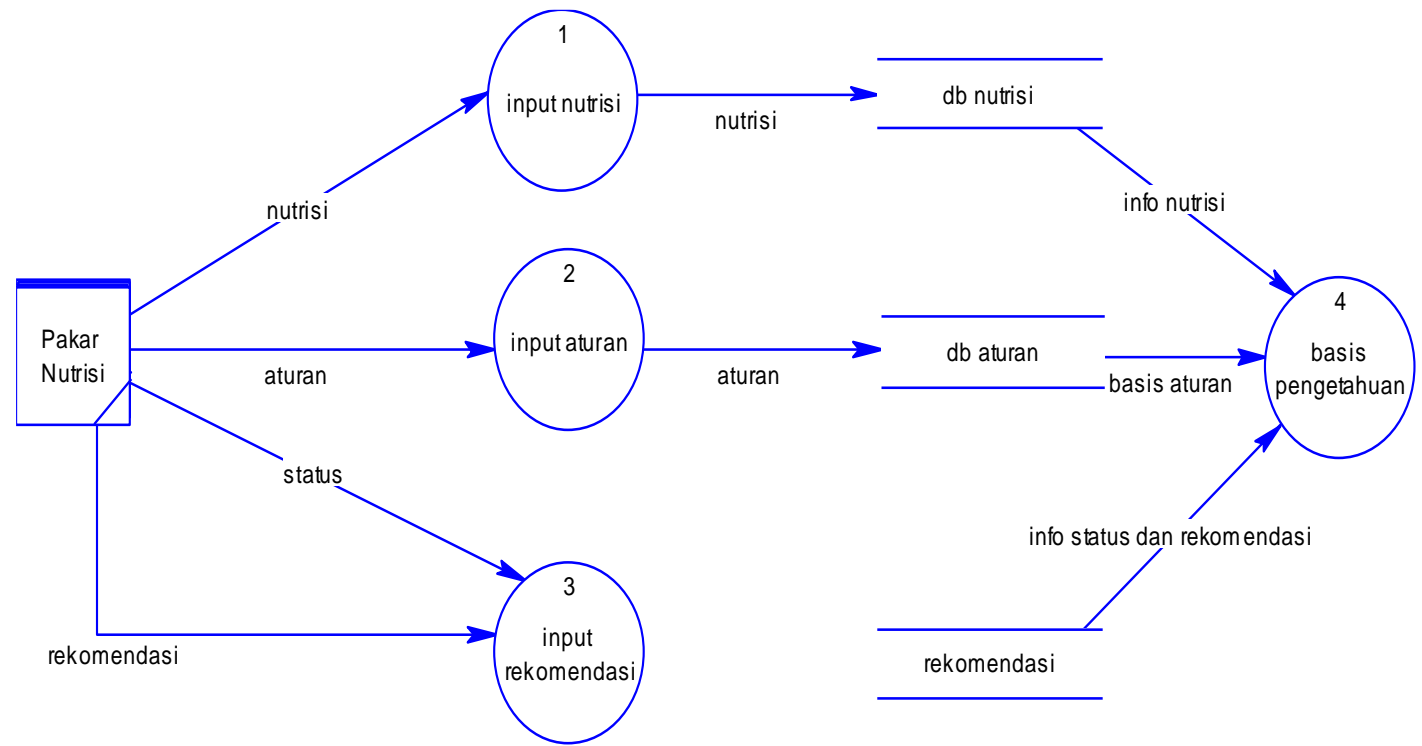

Gambar 4. Diagram Alir Data Level 1 Proses Basis Pengetahuan 

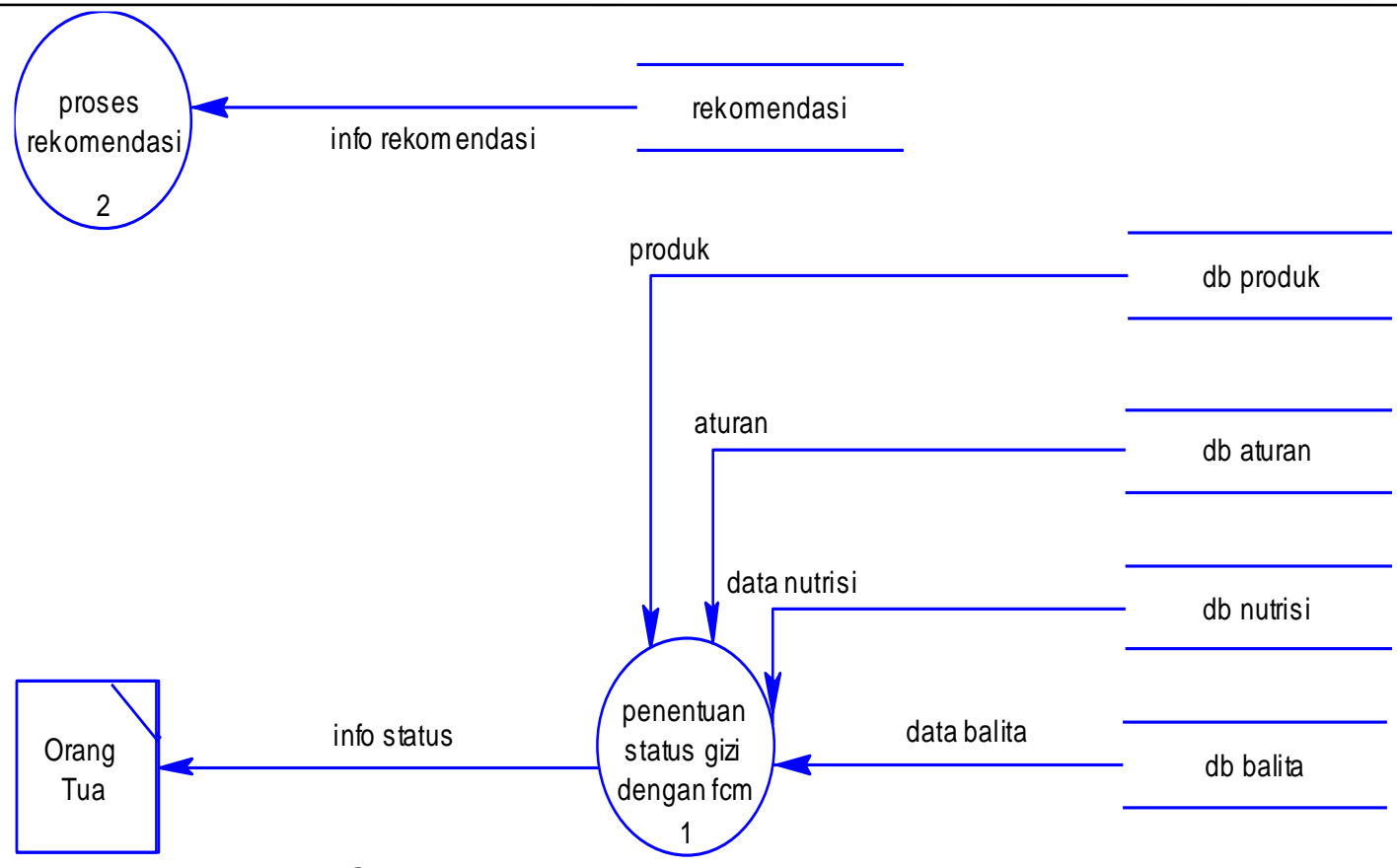

Gambar 5. Diagram Alir Data Level 1 Proses Rekomendasi

\subsection{Implementasi}

Gambar 6 menunjukkan tampilan saat aplikasi pertama kali diakses. Pengguna harus melakukan login terlebih dahulu dengan memasukkan username dan password agar dapat menggunakan aplikasi ini.

Pada Gambar 7 menampilkan menu pada aplikasi, yaitu menu home, menu cek status gizi \& produk, dan menu riwayat. Jika menu cek status gizi \& produk dipilih, maka pengguna dapat mengisikan kode batang pada produk seperti pada Gambar 8. Kemudian Gambar 9 menunjukkan informasi produk setelah mengisikan kode batang.

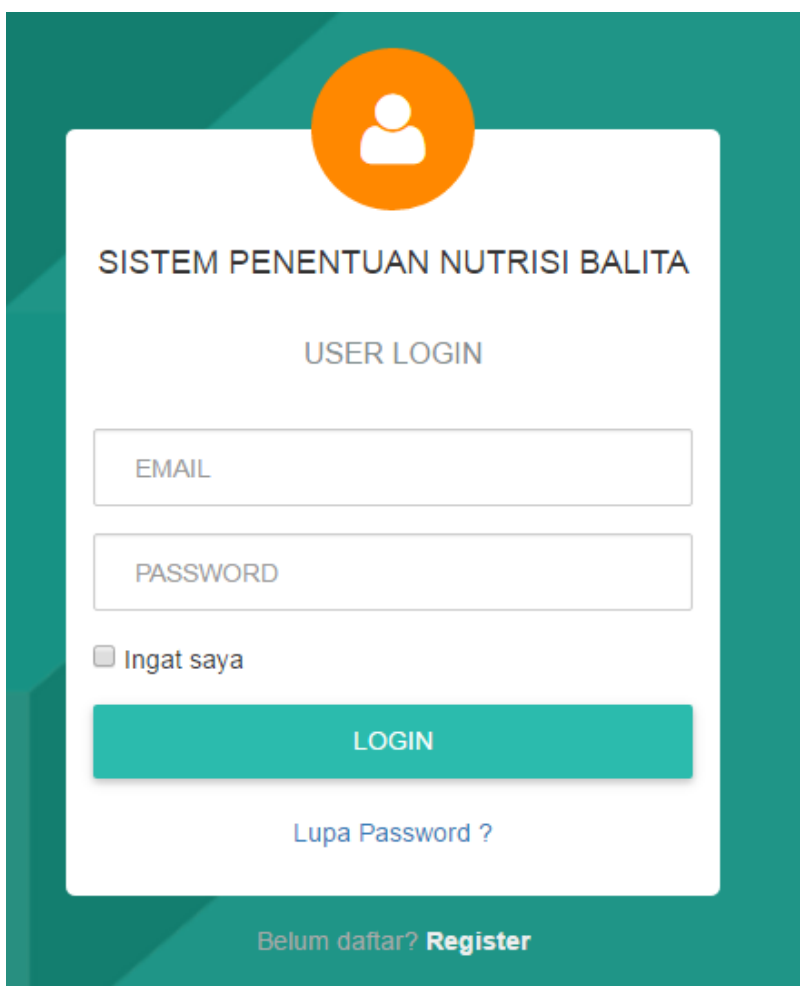

Gambar 6. Login 


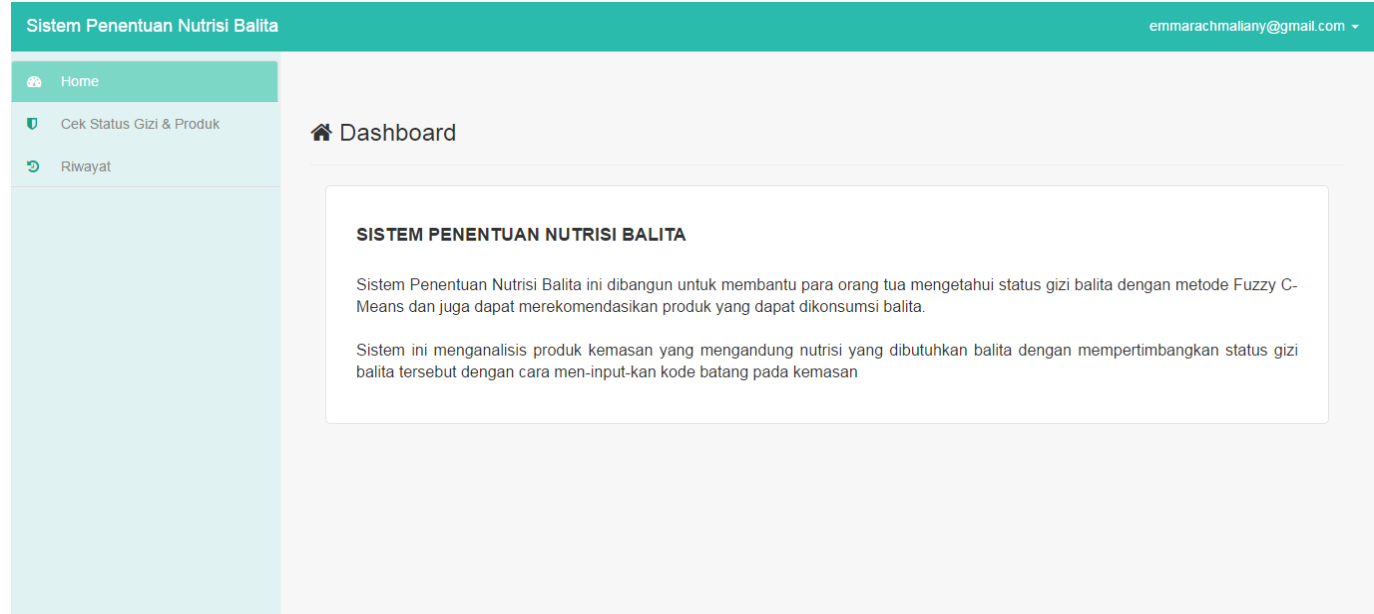

Gambar 7. Home atau Dashboard

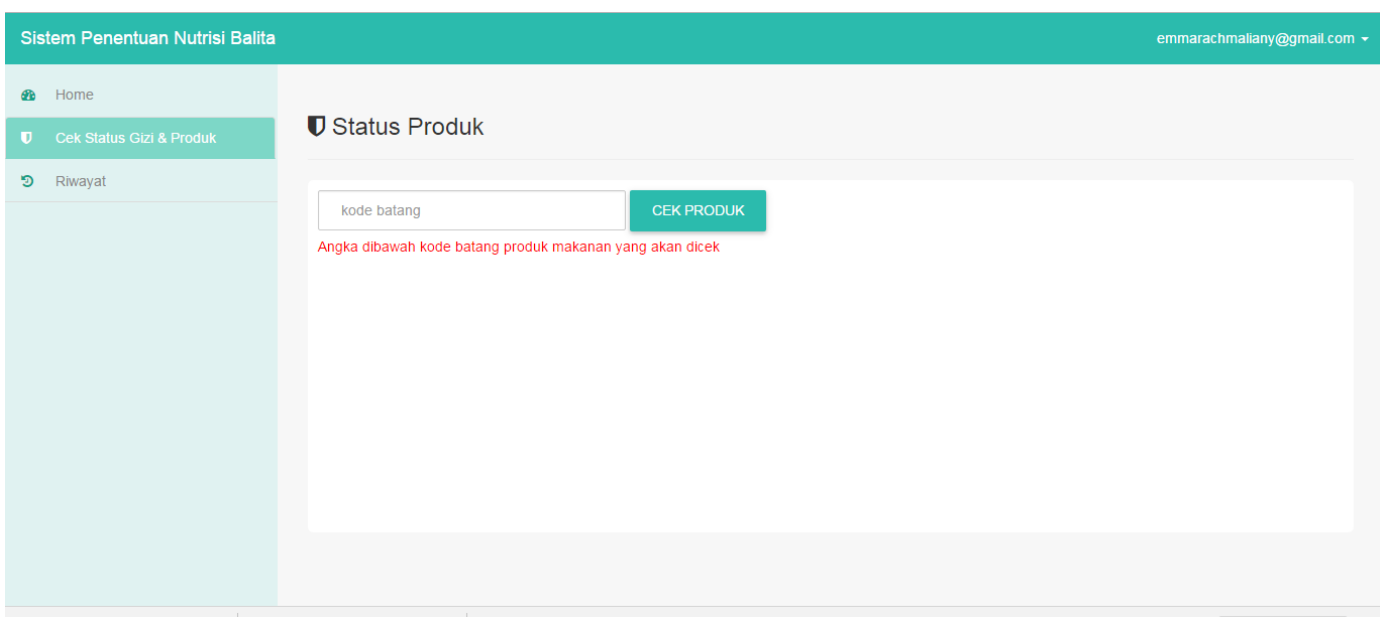

Gambar 8. Menu Cek Status Gizi \& Produk

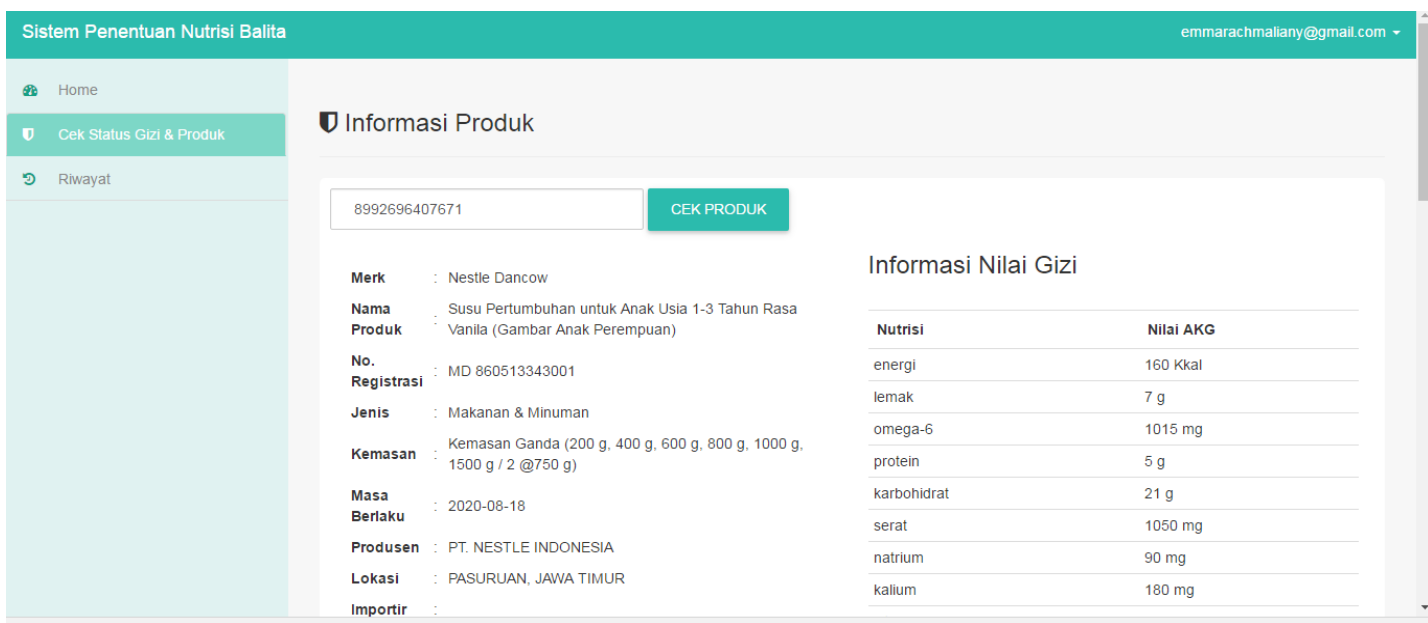

\section{Gambar 9. Informasi Produk}

Terakhir pada Gambar 10 menjelaskan beberapa data harus diisikan terkait balita seperti nama anak, usia, berat dan tinggi badan. Gambar 11 menjelaskan hasil dari FCM berupa status gizi pada anak, menampilkan rekomendasi berupa nutrisi yang dibutuhkan anak dan juga terkait dengan saran produk kemasan tersebut dapat dikonsumsi atau tidak. Gambar 12 menampilkan riwayat pengecekan setelah menggunakan pada sistem. 


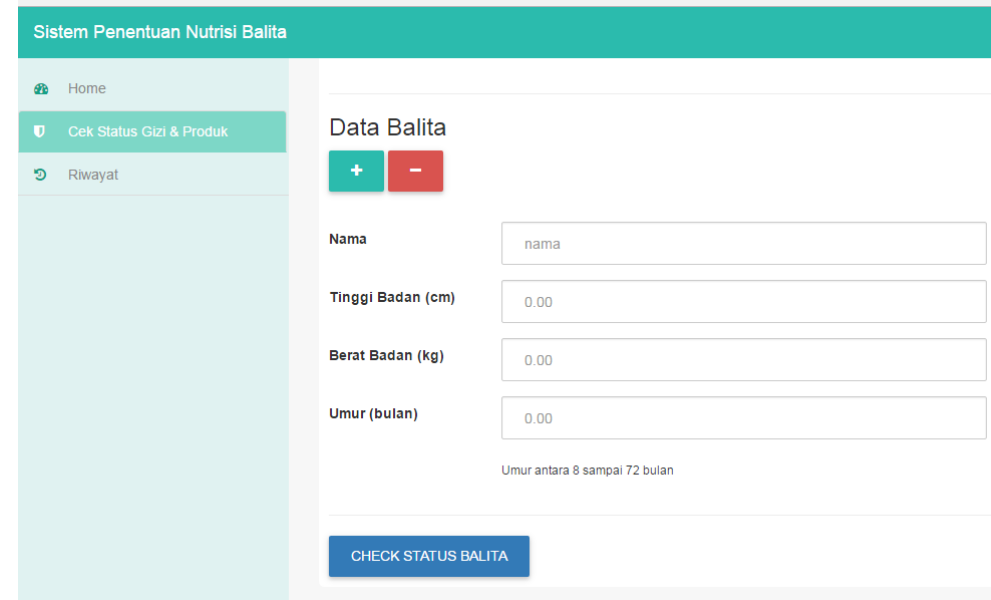

Gambar 10. Form Input Data Anak

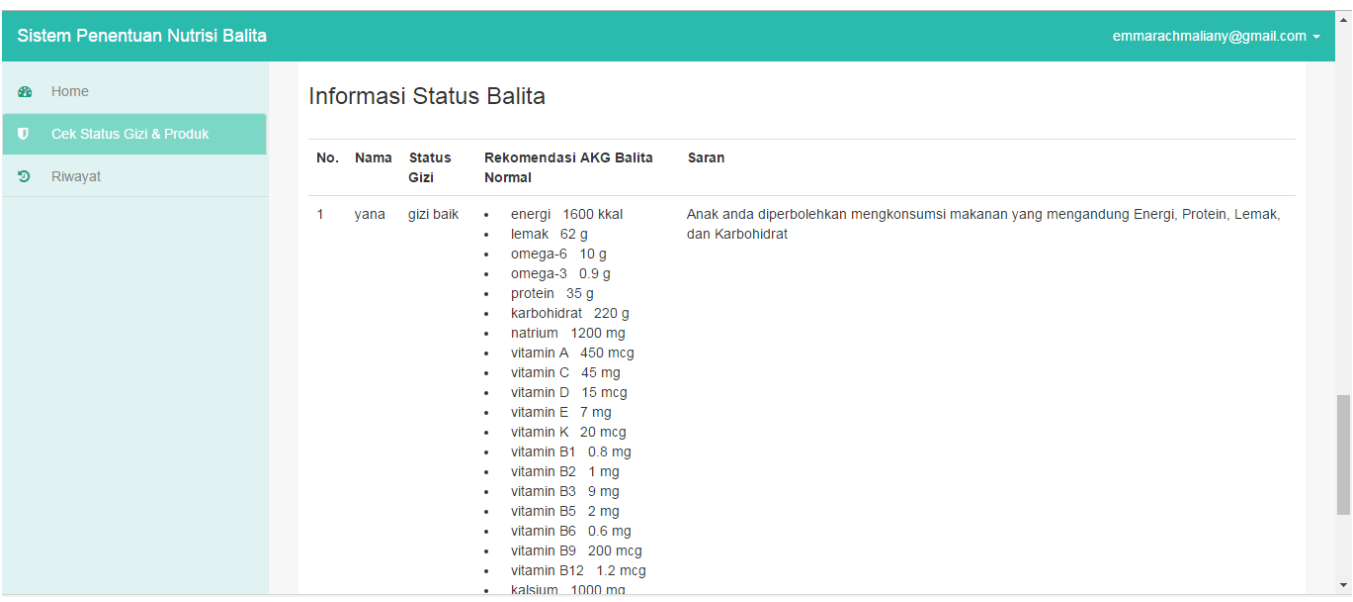

Gambar 11. Informasi Status Anak dan Rekomendasi

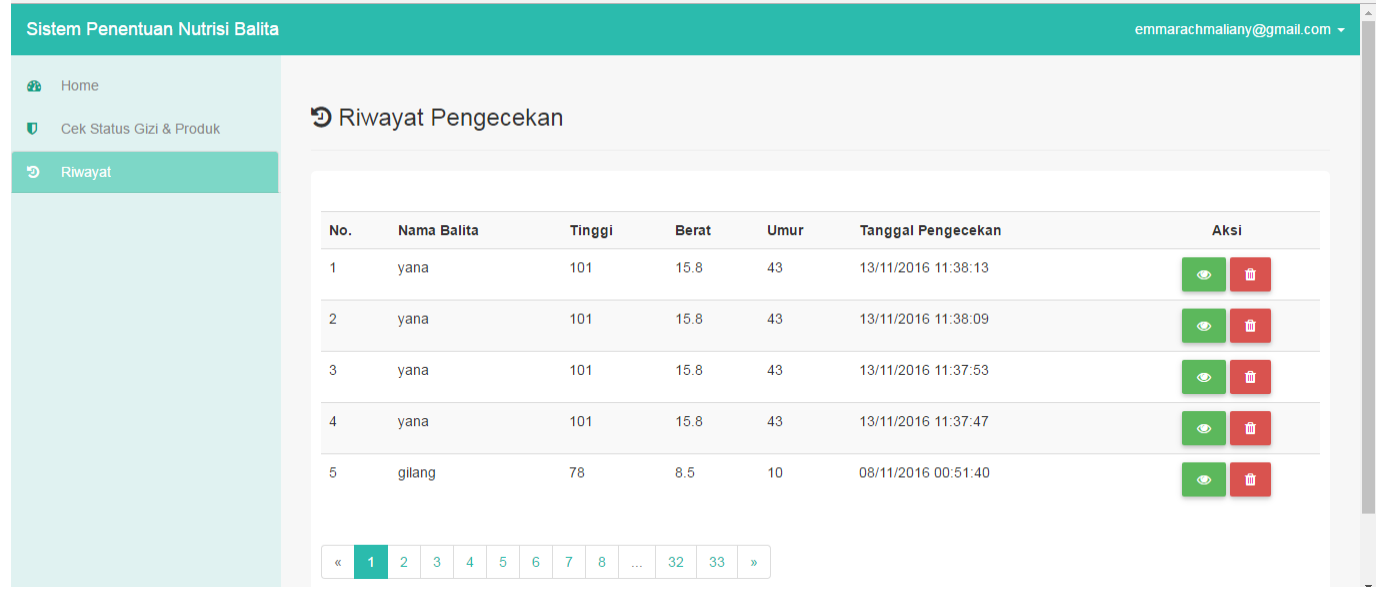

\section{Gambar 12. Riwayat Pengecekan}

\subsection{Pengujian Sistem (Testing)}

Pengujian dilakukan untuk mengetahui apakah sistem yang dibangun berjalan dengan baik atau tidak. Hasil dari pengujian User Acceptance Test (UAT) sebesar $89 \%$ yang artinya responden dapat menerima sistem, pengujian Usability Testing (UT) menggunakan metode System Usability Scale (SUS) sebesar 74,87\% acceptable seperti pada Tabel 1, dan pengujian knowledge sebesar $79 \%$ sudah sesuai dalam memberikan rekomendasi dan saran. 


\begin{tabular}{ccccccccccccc}
\hline & Q1 & Q2 & Q3 & Q4 & Q5 & Q6 & Q7 & Q8 & Q9 & Q10 & total & Skor SUS \\
\hline res 1 & 5 & 2 & 5 & 2 & 5 & 2 & 5 & 2 & 5 & 3 & 34 & 85 \\
\hline res 2 & 3 & 1 & 3 & 1 & 3 & 1 & 4 & 1 & 2 & 1 & 30 & 75 \\
\hline res 3 & 5 & 2 & 4 & 2 & 4 & 2 & 5 & 2 & 2 & 4 & 28 & 70 \\
\hline res 4 & 5 & 4 & 3 & 4 & 5 & 2 & 3 & 2 & 3 & 1 & 26 & 65 \\
\hline res 5 & 3 & 2 & 4 & 2 & 4 & 2 & 3 & 2 & 3 & 2 & 27 & 67,5 \\
\hline res 6 & 3 & 3 & 4 & 2 & 4 & 2 & 4 & 2 & 4 & 2 & 28 & 70 \\
\hline res 7 & 3 & 2 & 5 & 4 & 5 & 2 & 4 & 2 & 4 & 2 & 29 & 72,5 \\
\hline res 8 & 4 & 2 & 4 & 2 & 2 & 2 & 4 & 2 & 4 & 2 & 28 & 70 \\
\hline res 9 & 4 & 4 & 5 & 4 & 4 & 4 & 5 & 3 & 4 & 4 & 23 & 57,5 \\
\hline res 10 & 4 & 3 & 3 & 4 & 4 & 3 & 4 & 5 & 4 & 5 & 19 & 47,5 \\
\hline res 11 & 4 & 2 & 4 & 2 & 4 & 2 & 4 & 2 & 4 & 2 & 30 & 75 \\
\hline res 12 & 3 & 4 & 3 & 3 & 3 & 4 & 3 & 3 & 3 & 3 & 20 & 50 \\
\hline res 13 & 4 & 2 & 4 & 2 & 2 & 2 & 4 & 2 & 4 & 2 & 28 & 70 \\
\hline res 14 & 3 & 2 & 4 & 3 & 4 & 2 & 3 & 2 & 4 & 2 & 27 & 67,5 \\
\hline res 15 & 4 & 1 & 4 & 1 & 4 & 1 & 4 & 1 & 4 & 1 & 35 & 87,5 \\
\hline res 16 & 3 & 2 & 5 & 2 & 5 & 2 & 4 & 2 & 4 & 2 & 30 & 75 \\
\hline res 17 & 5 & 1 & 5 & 1 & 5 & 2 & 5 & 1 & 5 & 1 & 39 & 97,5 \\
\hline res 18 & 5 & 1 & 5 & 1 & 5 & 2 & 5 & 1 & 5 & 1 & 39 & 97,5 \\
\hline res 19 & 5 & 1 & 5 & 1 & 5 & 1 & 5 & 1 & 5 & 1 & 40 & 100 \\
\hline res 20 & 4 & 1 & 5 & 1 & 5 & 2 & 5 & 1 & 5 & 1 & 39 & 97,5 \\
\hline & & & & Total skor & & & & & 74,87 \\
\hline
\end{tabular}

Pengujian Persamaan 1 terhadap responden adalah jumlah skor yang didapatkan dari semua responden. Didapatkan skor 74,87 (dengan skala $0 . .100$ ).

$$
\frac{\text { jumlah score semua responden }}{\text { jumlah responden }}
$$

Tabel 2. Hasil Pengujian Usability Testing

\begin{tabular}{ccccc}
\hline No. & Kategori & Rentan skor & Jumlah & Persentase \\
\hline 1 & Not Acceptable & $0-50$ & 2 & $20 \%$ \\
\hline 2 & Marginal & $50-70$ & 8 & $80 \%$ \\
\hline 3 & Acceptable & $70-100$ & 10 & $100 \%$ \\
\hline
\end{tabular}

Dari tabel referensi Tabel 2 didapatkan kesimpulan bahwa dengan rata-rata penilaian UT mendapatkan skor 74,87 (skala 0..100). Dengan demikian, dapat dinyatakan aplikasi penentuan nutrisi anak dengan menggunakan Fuzzy C-Means masuk dalam kategori acceptable sehingga efektif membantu user dalam penggunaan aplikasi.

\section{Kesimpulan}

Berdasarkan hasil pembahasan, maka dapat disimpulkan sebagai berikut:

1. Telah dibangun aplikasi penentuan nutrisi yang dapat membantu orang tua untuk mengetahui status gizi anak dengan menerapkan algoritma FCM dengan validasi sebesar $83 \%$.

2. Hasil dari pengujian UAT sebesar $89 \%$ dapat menerima, pengujian UT sebesar $74,87 \%$ acceptable, dan pengujian knowledge sebesar $79 \%$ sudah sesuai dalam memberikan rekomendasi dan saran.

3. Sistem dapat mengelompokkan status gizi menjadi 3 cluster, yaitu gizi baik, gizi kurang, dan gizi lebih, berdasarkan data anak yang telah dimasukkan ke dalam sistem. 
Referensi

[1] S. D. Lumbawa, "Sistem Pakar Mendeteksi Gizi Buruk Pada Balita Berbasis Web Dengan Menggunakan Metode Certainty Factor," Pelita Informatika Budi Darma, Vol. 5, No. 1, 2013.

[2] M. Dianingrum and A. Suryanto, "Penentuan Status Gizi Balita Berbasis Android Menggunakan Metode Analitycal Hierarchy Process (AHP)," Jurnal Informatika, Vol. 3, No. 1, 2014.

[3] L. Madeso, "Rancang Bangun Sistem Pakar Penentuan Status Gizi Pada Balita Menggunaka Metode Forward Chaining," E-Jurnal UNSRIT, Vol. 2, No. 2, 2015.

[4] Y. Pramitarini, I. Purnama, and M. Purnomo, "Analisa Rekam Medis Untuk Menentukan Status Gizi Anak Balita Menggunakan Naive Bayes Classifier," In Prosiding Seminar Nasional Manajemen Teknologi XVII, 2015.

[5] F. Hariri and D. Pamungkas, "Implementasi Naïve Bayes Classifier Untuk Diagnosa Status Gizi Balita," In Seminar Nasional Teknologi Dan Multimedia (SEMNASTEKNOMEDIA), 2016.

[6] F. Al Irsyadi, "Klasifikasi Status Gizi Balita Jenis Kelamin Laki-Laki Menggunakan Jaringan Syaraf Tiruan," Khazanah Informatika: Jurnal IImu Komputer dan Informatika, Vol. 1, No. 1, Pp. 16-22, 2015.

[7] F. Fitri, O. Setyawati, and D. Rahadi, "Aplikasi Jaringan Syaraf Tiruan Untuk Penentuan Status Gizi Balita Dan Rekomendasi Menu Makanan Yang Dibutuhkan," Jurnal EECCIS, Vol. 7, No. 2, Pp. 119-124, 2014.

[8] A. Romadhon and A. Purnomo, "Sistem Pendukung Keputusan Untuk Menentukan Status Gizi Balita Menggunakan Metode Fuzzy Inferensi Sugeno (Berdasarkan Metode Antropometri)," Informal Informatics J., Vol. 1, No. 3, Pp. 78-87, 2016.

[9] N. Hermaduanti and S. Kusumadewi, "Sistem Pendukung Keputusan Berbasis Sms Untuk Menentukan Status Gizi Dengan Metode K-Nearest Neighbor," S Seminar Nasional Aplikasi Teknologi Informasi (SNATI), Vol. 1, No. 1, 2008.

[10] J. Susanto, "Rancang Bangun Aplikasi Penilaian Status Gizi Dan Penentuan Menu Makanan," In Seminar Nasional Sistem \& Teknologi Informasi (SNASTI), 2011.

[11] T. Rismawan And S. Kusumadewi, "Aplikasi Algoritma Genetika Untuk Penentuan Komposisi Bahan Pangan Harian," In Seminar Nasional Aplikasi Teknologi Informasi (SNATI), 2007.

[12] S. Kusumadewi, "Klasifikasi Kandungan Nutrisi Bahan Pangan Menggunakan Fuzzy CMeans," In Seminar Nasional Aplikasi Teknologi Informasi, 2007.

[13] I. M. Yuliansyah, Herman., Sri Winiarti, Sri Kusumadewi, "Pengembangan Aplikasi Android Untuk Penentuan Nutrisi Balita Terhadap Konsumsi Produk Makanan Kemasan," In Seminar Nasional Aptikom (SEMNASTIKOM), 2016. 